\title{
KONSELING AGAMA DENGAN PENDEKATAN BUDAYA DALAM MEMBENTUK RESILIENSI REMAJA
}

\author{
Yuliana Nelisma, Wahidah Fitriani, Silvianetri \\ UIN Ar-Raniry Banda Aceh, \\ Institut Agama Islam Negeri Batusangkar \\ Institut Agama Islam Negeri Batusangkar \\ nelismabk@gmail.com, wahidahfitriani@iainbatusangkar.ac.id, \\ silvianetri.71@gmail.com
}

\begin{abstract}
ABSTRAK
Tujuan penelitian ini berfokus pada konseling agama dengan menggunakan pendekatan budaya dalam membentuk resiliensi remaja. Konseling dapat dicirikan sebagai cara yang paling umum untuk memberikan bantuan kepada klien oleh seorang konselor dengan hubungan yang bersifat individu ke individu, meskipun mempengaruhi lebih dari satu individu. Penelitian ini menggunakan jenis/metode penelitian berupa studi kepustakaan (Library Research) yang memiliki relavansi mengenai konseling agama pendekatan budaya dalam membentuk resiliensi remaja. Tujuan konseling budaya memiliki beberapa tindakan dalam konseling yaitu pertama, konseling dapat membuat konselor peka terhadap masalah lingkungan yang mempengaruhi perkembangan manusia. Kedua, profesi konseling mengharuskan konselor memiliki pengetehuan dan keterampilan. Konseling agama merupakan bantuan dari konselor untuk membantu klien membangkitkan ajaran agamanya untuk menyelesaikan segala permasalahan hidup yang dihadapi dengan cara-cara yang dibenarkan menurut agama dan keyakinannya.
\end{abstract}

Kata Kunci : Konseling Agama Pendekatan Budaya, Resiliensi Remaja

\section{RELIGIOUS COUNSELING WITH CULTURAL APPROACH IN FORMING ADOLESCENT RESILIENCE}

\begin{abstract}
The purpose of this study focuses on religious counseling using a cultural approach in shaping adolescent resilience. Counseling can be characterized as the most common way of providing assistance to clients by a counselor with an individual to individual relationship, even though it affects more than one individual. This research uses the type/method of research in the form of a literature study (Library Research) which has relevance to religious counseling with a cultural approach in shaping adolescent resilience. The purpose of cultural counseling has several actions in counseling, namely first, counseling can make counselors sensitive to environmental problems that affect human development. Second, the counseling profession requires that counselors have knowledge and skills. Religious counseling is assistance from counselors to help clients awaken their religious teachings to solve all life problems they face in ways that are justified according to their religion and beliefs.
\end{abstract}

Keywords: Religious Counseling Close to Culture, Adolescent Resilience 


\section{PENDAHULUAN}

Manusia tidak dapat dipisahkan dari budaya. Dengan memandang masyarakat sebagai tempat di mana orang-orang bertindak, dapat diperoleh gambaran yang lebih jelas tentang orang-orang dan hal-hal di balik perkembangan perilaku pada orang-orang dan secara mengejutkan masalah-masalah yang dialami orang (termasuk remaja). Selain itu juga dapat memahami perkembangan karakter pada orang yang berhubungan dengan setting sosial dimana mereka berada.

Konseling dapat dicirikan sebagai cara paling umum untuk memberikan bantuan melalui wawancara konsultasi oleh seorang spesialis (penasihat) kepada orang-orang yang menghadapi masalah (pelanggan), yang mendorong tujuan dari masalah yang dilihat oleh pelanggan. Pengarahan adalah hubungan ahli antara advokat yang disiapkan dan konseli. Hubungan-hubungan ini umumnya bersifat individu ke individu, meskipun di sana-sini mempengaruhi lebih dari satu individu. Nasihat dimaksudkan untuk membantu pelanggan dengan pemahaman dan memperjelas perspektif mereka tentang kehidupan, dan untuk mencapai tujuan keyakinan diri.

Konseling dapat digunakan sebagai metodologi yang sangat layak dalam membangun kualitas dunia lain bagi orang-orang. Membimbing adalah panggilan bantuan yang mendasari pekerjaan dan elemen orang di arena publik. Metodologi pembinaan yang dimaksud adalah penyuluhan yang sesuai dengan kualitas yang dianut oleh daerah setempat. Nasihat Islami adalah bantuan yang diberikan kepada orang-orang dan perkumpulan untuk memahami kembali realitas mereka sebagai hewan Tuhan yang harus hidup selaras dengan pengaturan dan petunjuk Tuhan. Secara khusus, penyutradaraan Islami adalah sebuah karya untuk membantu orang-orang dalam menemukan cara untuk menciptakan fitrah dan juga kembali ke alam, dengan memungkinkan keyakinan, akal dan kehendak yang diberikan oleh Allah (Irman et al., 2020).

Konseling agama adalah bantuan dari instruktur untuk membantu pelanggan dengan membangkitkan pelajaran ketat mereka untuk mengatasi setiap masalah kehidupan yang mereka hadapi dengan sopan santun yang dipertahankan oleh agama dan keyakinan mereka. Berdasarkan pengertian di atas, cenderung terlihat bahwa pengarahan dan pembinaan yang tegas memiliki bidang perkembangan yang luas dengan berbagai persoalan yang dilirik oleh masyarakat. Dari rencana di atas, ternyata pengarahan Islami adalah suatu tindakan yang "bermanfaat" yang disebut tolong-menolong mengingat pada dasarnya orang yang perlu hidup sesuai dengan petunjuk Allah (jalan yang lurus), Al-Qur'an dan sunnah. dari Kurir- 
Nya untuk bertahan di dunia dan di luar yang besar.

Secara sosiologis, secara mental, agama adalah perilaku manusia yang diresapi dengan sifat-sifat ketat, yaitu vibrasi internal yang dapat mengarahkan dan mengendalikan perilaku manusia, baik sebanding dengan Tuhan (cinta) maupun dengan individu manusia, diri sendiri, dan faktor nyata yang berbeda (Dinda Kartika \& Oktafia, 2021). Menurut James Martineau sebagaimana dikutip oleh Nina Aminah, agama adalah kepercayaan kepada Tuhan yang hidup secara konsisten, tepatnya roh dan kehendak surgawi yang mengawasi alam semesta dan memiliki hubungan etis dengan umat manusia. Islam yang telah memberikan kontribusi keengganan untuk meminta kehidupan melalui syari'at, kepatuhan untuk berdoa dalam beberapa kali, keengganan untuk apa yang sebenarnya besar dan apa yang menjijikkan dan mencapai sesuatu yang bermanfaat dan menghindari kejahatan (amar makruf nahi munkar), mempengaruhi perkembangan dari etika yang baik. Agung. Inilah hal-hal yang ditambahkan Islam ke dalam pengembangan cara hidup negara. Menurut sudut pandang sosial, semua pertemuan ketat di Indonesia telah memupuk budaya yang ketat untuk menggantikan mereka yang tidak terlalu memperhatikan kontras yang ketat, etnis dan ras.

\section{METODE PENELITIAN}

Penelitian ini menggunakan jenis/pendekatan penelitian berupa studi kepustakaan (Library Research). Penulis mengumpulkan data dan kemudian mengkaji buku-buku ataupun sumber bacaan yang lain yang memiliki relavansi dengan mengenai konseling agamapendekatan budaya dalam membentuk resiliensi remaja.

\section{HASIL DAN PEMBAHASAN}

\section{Konseling Agama Pendekatan Budaya}

Konseling adalah Kursus memberi bantuan melalui hubungan antara pemandu dan pelanggan, untuk memperoleh pemahaman dan pencapaian tujuan dalam mengarahkan, komponen pengaruh mendasar di antaranya adalah bahasa, dapat menjadi alat vital. Dalam kegiatan-kegiatan yang dilakukan oleh para pemandu, secara khusus lebih menitikberatkan pada kondisi yang dialami oleh pengajar dengan cara menoleransi kondisi orang lain dengan cara menghargai, dan memperhatikan perasaan orang lain sesuai dengan komponen sosial pada masyarakat umum yang terjadi di sekitarnya. Berpikir kritis individu kemungkinan akan berkaitan dengan cara hidup yang mempengaruhi individu tersebut (Rofiqi, 2019). Advokat harus lebih peka dan harus memahami bahwa hidup tergantung pada banyak 
kualitas yang berlaku secara keseluruhan dan eksplisit untuk membangun kepercayaan bagi pelanggan. Melalui sifat-sifat yang berlaku secara lokal, penasehat akan memiliki pandangan yang layak untuk memiliki pilihan untuk mengarang jiwa pelanggan untuk memiliki pilihan untuk mencapai sesuatu, membangun kemampuan untuk menjadi kepastian sadar diri. Ketajaman atau perspektif seorang instruktur yang dapat membantu dengan mendorong pelanggan merupakan langkah awal bagi pemandu untuk melakukan pengarahan. Oleh karena itu, untuk situasi ini, komponen sosial yang dipertimbangkan dalam membimbing diperiksa.

Kewaspadaan yang ketat adalah bagian penting dari bagian dari peningkatan dewasa muda yang harus ditumbuhkan secara ideal, sehingga pemuda memiliki penguatan hidup yang kuat, khususnya kebajikan, terutama yang dimulai dari agama, sehingga remaja memperoleh pengembangan kerangka etika yang mengarahkan perilaku mereka. dalam kehidupan sehari-hari. hari. Kewaspadaan yang ketat pada orang muda harus terlihat dalam sudut pandang seremonial, antara lain melalui latihan petisi dalam kehidupan sehari-hari. Latihan permohonan sangat penting untuk kesadaran ketat remaja (Wati \& Silvianetri, 2018).

Sesuai dengan referensi Kata Besar Bahasa Indonesia, budaya mengandung pengertian pertimbangan, akal, hasil, adat atau sesuatu yang telah berubah menjadi suatu kecenderungan yang sulit diubah (Nashihin, 2017). Budaya adalah gaya hidup yang diciptakan dan dimiliki bersama oleh sekelompok individu dan diturunkan dari satu zaman ke zaman lainnya. Budaya terdiri dari banyak komponen yang rumit, termasuk kerangka kerja yang ketat dan politis, adat istiadat, dialek, instrumen, pakaian, struktur, dan karya agung. Bahasa, mirip dengan budaya, adalah bagian individu yang tidak dapat dibedakan, individu yang tak terhitung jumlahnya seperti itu umumnya akan menganggapnya diperoleh secara turun temurun. Ketika seseorang mencoba untuk berbicara dengan orang-orang dari berbagai masyarakat dan mengubah perbedaan mereka, itu menunjukkan bahwa cara hidup dipelajari (Thabroni, 2020)

Kebudayaan menurut Koentjaraningrat dalam (Mahfuz, 2019) adalah keseluruhan kerangka, pemikiran, kegiatan, dan akibat kerja manusia dalam kaitannya dengan kehidupan daerah setempat yang dijadikan milik manusia dengan belajar. Jadi budaya diperoleh melalui pembelajaran. Kegiatan yang dipelajari meliputi cara makan, minum, berpakaian, berbicara, beternak, bekerja, dan berhubungan dengan masyarakat yaitu budaya. Padahal, budaya tidak hanya ditemukan dalam masalah-masalah khusus, melainkan dalam pemikiran 
yang terkandung di otak yang kemudian muncul dalam karya, permintaan sosial, sikap kerja keras dan sudut pandang. Yojachem Wach mengatakan tentang dampak yang tidak signifikan dari agama pada budaya manusia yang secara ajaib hubungan agregat bergantung pada kemungkinan Tuhan. Kolaborasi sosial dan ketat dirancang tentang bagaimana mereka merenungkan Tuhan, hidup dan membayangkan Tuhan.

Leslie White mengatakan bahwa pangkal dari semua tingkah laku manusia tercermin pada simbol-simbol yang tertuang dalam seni, religi dan kekuasaan, dan semua aspek simbolik tadi tampak dalam bahasa. Kebudayaan juga merupakan fenomena yang selalu berubah sesuai dengan alam sekitarnya dan keperluan suatu komunitas (Supriatna, 2019). Kebudayaan meliputi segala manifestasi dari kehidupan manusia yang berbudi luhur dan yang bersifat rohani, misalnya: agama, kesenian, filsafat, ilmu pengetahuan, tata negara. Ciri khas bagi pendapat itu adalah perbedaan yang dibuat antara bangsa-bangsa berbudaya (yang beradab tinggi) dan bangsa- bangsa alam (yang dianggap lebih primitif). Sehingga manusia dengan daya pikirnya, diharapkan mampu untuk memilah

Konseling budaya memiliki beberapa tindakan dalam konseling, pertama, konseling dapat membuat konselor peka terhadap masalah lingkungan yang mempengaruhi perkembangan manusia. Kedua, profesi konseling mengharuskan konselor memiliki pengetehuan dan keterampilan untuk berkomunikasih tentang perlunya perubahan dan tindakan kolaboratif (Firman, 2017).

Konseling Agama dan budaya yaitu proses pemberian bantuan dari seorang konselor terhadap konseli yang berbeda agama dan latar belakang budaya. Budayaan mencakup semuanya yang di dapatkan atau dipelajari oleh manusia sebagai anggota masyarakat. Budaya terdiri dari segala sesuatu yang dipelajari dari pola-pola perilaku yang normatif. Artinya, mencakup segala cara-cara atau pola-pola berpikir, merasakan dan bertindak. konseling budaya bukan hanya melihat tetapi hendak memahami bagaimana keterlibatan integritas konselor tersebut kepada sikap konseli dalam nilai agama, nilai budaya konseli tersebut, serta sikap fleksibel, sikap positif dan kepuasan praktis, serta dapat menghadirkan eksisten diri dan ekspresi diri seseeorang yang memiliki budaya.

Hubungan agama dengan kebudayaan dalam kehidupam masyarakat kedua lembaga ini selalu ada dan selalu berhubungan. Keduanya saling memengaruhi. Agama memengaruhi budaya, dan budaya pun memengaruhi agama. Pengalaman dan pengetahuan beragama akan memberikan "warna" tersendiri dalam agama dan 
budaya. Aplikasi beragama dan berduya akan ditentukan oleh ketiga aspek tersebut. Aspek budaya akan lebih dominan dalam aplikasi agama. Sehingga, seringkali prilaku budaya “dianggap" norma agama (Islam), tetapi sesungguhnya bukanlah norma/nilai agama.

\section{Fungsi Konseling Agama dan Budaya}

Agama dan budaya adalah kedua hal penting yang tidak bisa di pisahkan. Agama adalah bagian dari kebudayaan. Sekalipun pada masa kini cenderung agama dan kebudayaan dianggap sebagai perbedaan, namun perbedaan Agama dan Budaya tidak harus membuat konselor atau konseli bermusuhan atau melakukan perdebatan tetapi perbedaan tersebut dapat diterima ketika pendeta sebagai konselor mampu belajar juga dari pengalaman iman yang dialami dan diyakini oleh klien (Mahfuz, 2019).

Berkenaan dengan menjadi pemandu, Augsburger berpendapat bahwa advokat yang cakap secara sosial diakui oleh lima kualitas yang dapat diukur dan dipelajari yang mengamankan mereka, konseli, dan sistem konseling, khususnya sebagai berikut: a) Penasihat yang memiliki kesadaran sosial memiliki pemahaman yang masuk akal tentang kualitas - kualitas sosialnya sendiri dan kecurigaan mendasar. Mereka merasakan kecenderungan manusia mana yang mereka anggap cocok atau tidak pantas, menarik atau menyusahkan, menyusun atau menghancurkan kehidupan. Mereka sepenuhnya sadar bahwa orang lain memiliki berbagai kualitas dan anggapan, yang sah dalam hal apa pun, ketika kualitas dan kecurigaan itu berbeda dari apa yang mereka dapatkan, b) Pemandu yang sadar sosial memiliki kemampuan untuk menyambut, memasuki, dan menghargai perspektif pada orang lain tanpa menyangkal keaslian mereka. Mereka dapat merasakan belas kasih yang diharapkan menjadi basis sosial yang khas, dan merasa baik dalam batas-batas perspektif. Mereka dapat memasuki alam semesta orang lain, merasakan perbedaan, dan menyukai perbedaan, namun dari satu sudut pandang mempertahankan keunikan realitas mereka sendiri. Penasihat yang berwawasan sosial mencari sumber dampak pada individu dan lingkungan, model dan kondisi individu. Kegiatan dan penghibur, praktik dan pengaturan, kolaborasi menasihati eksplisit dan kondisi sosial harus dilihat, dipahami, dan dianggap, c) Penasihat yang sadar sosial dapat melewati hipotesis, arahan, atau strategi pengarah, dan menjadi orang yang layak. Mereka benar-benar campur aduk dalam menasihati mereka, bukan dalam pilihan strategi yang sewenang-wenang yang bekerja namun dalam kemampuan beradaptasi logis yang memungkinkan mereka untuk memilih pengaturan khusus dari kemampuan membimbing sebagai pilihan yang dianggap sesuai dengan pengalaman berharga konseli tertentu. Pemandu yang sadar sosial menganggap diri mereka 
sebagai penduduk inklusif yang berhubungan dengan semua orang tetapi juga khusus dari mereka masing-masing. Mereka hidup di dunia ini, bukan hanya lokal atau negara (Farikhatul 'Ubudiyah, 2020).

\section{Unsur-unsur Konseling Agama Pendekatan Budaya}

Komponen kebudayaan meliputi hal-hal sebagai berikut: a. Kebudayaan Material (Material), adalah jenis kebudayaan sebagai barang-barang substansial karena karya manusia, seperti rumah, kendaraan, tempat-tempat suci, pencatat waktu, barang-barang inovatif, dll. b. Kebudayaan non-materi (mendalam) adalah jenis kebudayaan yang bukan sebagai barang-barang substansial, yang merupakan konsekuensi dari inovasi dan selera manusia, misalnya, 1) Manifestasi manusia, seperti cara berpikir dan ilmu pengetahuan, baik sebagai hipotesis murni maupun yang telah terakumulasi untuk dipoles dalam kehidupan lokal (ilmu murni dan ilmu terapan). 2) Konsekuensi dari sentimen manusia, sebagai kualitas dan praktik yang diterima berbeda yang harus dilakukan untuk mengelola masalah sosial dari perspektif yang luas, termasuk (agama, bukan pengungkapan), sistem kepercayaan, misteri, dan semua komponen yang merupakan efek lanjutan dari artikulasi jiwa. . orang sebagai warga negara (Awad, 2015).

Dalam pengkajian isu tentang budaya (Ganesan, 2016) mengemukakan tiga unsur pokok dalam konseling budaya, yaitu:

1. Individu adalah penting dan khas.

2. Konselor membawa nilai-nilai yang berasal dari lingkungan budayanya.

3. Klien yang datang menemui konselor juga membawa seperangkat nilai dan sikap yang mencerminkan budayanya.

Selain itu, Brown mengungkapkan bahwa pencapaian bantuan konseling sangat dipengaruhi oleh variabel bahasa, nilai, generalisasi, kelas sosial, identitas, dan lebih jauh lagi jenis kelamin. Menurut Sue, faktor-faktor sosial yang mempengaruhi pembinaan terlihat pada gagasan naluri manusia, arah waktu, hubungan dengan alam, dan arah kegiatan. Dengan cara demikian, Clemon E. Vontres dalam pertukarannya dengan Morris Jacson merekomendasikan bahwa budaya terdiri dari lima lingkaran sosialisasi yang mencakup dan memengaruhi mentalitas, kualitas, dan bahasa. Lima derajat yang dimaksud meliputi: koneksi umum (dunia), lingkungan publik (bangsa), lokal, ras, dan etnis. Komponenkomponen ini mempengaruhi orang-orang sebagai orang-orang dalam berbagai jenis kondisi (Mirnawati et.al., 2016). 
Unsur-unsur pokok yang perlu diperhatikan dalam konseling lintas budaya adalah sebagai berikut:

1. Klien sebagai individu yang unik, yang memiliki unsur-unsur budaya tertentu yang berpengaruh pada sikap, bahasa, nilai-nilai, pandangan hidup, dan sebagainya.

2. Konselor sebagai individu yang unik juga tidak terlepas dari pengaruh unsurunsur budaya seperti halnya klien yang dilayani.

3. Dalam hubungan konseling konselor harus menyadari unsur-unsur tersebut dan menyadari bahwa unsur-unsur budaya itu akan mempengaruhi keberhasilan proses konseling.

\section{Resiliensi Remaja}

Masa muda yang luar biasa harus terlihat berdasarkan hal yang ditampilkan, termasuk penampilan sebagai petunjuk perasaan manusia. Beberapa ribu tahun sebelumnya Cicero berkata: wajah adalah gambaran dari roh. Faktanya adalah bahwa sentimen dan perasaan manusia sering terlihat di wajah mereka dan dapat dirasakan melalui artikulasi yang berbeda (Sunarti et al., 2018). Tahap dewasa muda harus terlihat dari penampilan, sinyal, daya pikir, menangani perasaan dalam berkomunikasi, kepatuhan dalam cinta dan lain-lain. Sehingga dengan melihat tingkah laku kaum muda, akan sangat terlihat kondisi mental, sosial, dan dunia lain mereka yang akan membantu orang dewasa menjadi lebih bijak dalam memperlakukan kaum muda dalam mencapai tujuan dan masa depan mereka.

Pemuda saat ini semakin dibutuhkan untuk memiliki fleksibilitas untuk mencegah gangguan tugas formatif, kepuasan pribadi, dan masa depan mereka. Tinjauan ini dimaksudkan untuk memperluas fleksibilitas dewasa muda dan unsur-unsur biologis yang mempengaruhinya (Sunarti et al., 2017). Kapasitas keluwesan pada remaja Jawa dipengaruhi oleh keserbagunaan keluarga, teman, dan sosial Jawa dari rila, narima, dan ketekunan, legalisme dan iklim sosial. Anak-anak yang mengalami pergumulan dalam keluarga dapat melepaskan diri dari ketegangan dan bangkit dari peristiwa-peristiwa buruk sebelumnya. Fleksibilitas menggabungkan kapasitas remaja untuk menjauhkan diri dari tekanan menyedihkan atau melankolis yang mereka alami dan tetap berguna (Rifaudin \& ., 2021).

Perpisahan orang tua merupakan suatu keanehan yang muncul setiap tahunnya, hal tersebut dapat menimbulkan dampak yang berbeda-beda pada anak-anak, khususnya pada masa remajanya. Sebagian akibat yang ditimbulkan oleh perpisahan orang tua pada remaja adalah menimbulkan masalah, stres, dan cedera. Kapasitas fleksibilitas dapat mengambil bagian yang signifikan dalam mengurangi efek perpisahan orang tua. Kekuatan framing sebagai ciri ilmu otak positif dalam mengambil peran pada pemuda yang mengalami hal 
(Hermansyah \& Hadjam, 2020)

Masa muda atau ketidakdewasaan telah secara luas digunakan untuk menandakan fase progresif antara masa remaja dan dewasa, yang digambarkan oleh perubahan aktual yang luas seperti halnya pergantian peristiwa intelektual dan sosial (Masna, 2013). Jadi lembaga pendidikan bagi kaum muda adalah organisasi sosial tempat mereka tinggal, berkreasi dan berkembang. Di mana mereka menginvestasikan sebagian besar energi mereka, ada anak-anak muda yang berkumpul, remaja dan wanita dalam periode usia yang sama umumnya "setara" dengan mentalitas yang sama, remaja berbaur dan menghabiskan waktu bersama teman-teman mereka (Desmita, 2009)

Menjadi individu yang dicintai oleh banyak teman menyebabkan remaja memiliki pandangan yang baik atau senang terhadap dirinya sendiri (Desmita, 2009). Dengan berbagai keunggulan yang dimiliki melalui peer affiliation, memberikan kebebasan kepada generasi muda untuk memiliki kemampuan beradaptasi (versatility). Dengan tujuan agar remaja harus pandai dalam memilih teman untuk memiliki pengaruh positif dalam pergaulan. Juga, menjadi penting bagi sekelompok teman adalah pertemuan bagi anak-anak untuk mengubah diri mereka dalam kondisi yang berbeda dan dengan siapa pun. Namun, dengan perluasan afiliasi, masalah mulai muncul karena perbedaan dalam peningkatan karakter perkumpulan dan tingkat sosial, moneter, sosial yang berbeda dari masing-masing.

\section{KESIMPULAN}

Remaja dengan kekhasan perubahan dan kebutuhan secara personal, serta tuntutan dan tanggung jawab sosial menjadi penyebab munculnya berbagai masalah pada remaja. Sehingga dibutuhkan peran serta orang dewasa dalam memberikan bimbingan. Maka kenakalan dan krisis identitas pada remaja tidak akan terjadi ketika orang dewasa memahami, budaya suatu cara hidup yang berkembang dan dimiliki bersama oleh sebuah kelompok orang dan diwariskan dari generasi ke generasi. Konseling agama merupakan bantuan dari konselor untuk membantu klien membangkitkan ajaran agamanya untuk menyelesaikan segala problematika hidup yang dihadapi dengan cara-cara yang dibenarkan menurut agama dan keyakinannya. 


\section{DAFTAR PUSTAKA}

Awad, F. B. (2015). KonselingIslam dalamMasyarakat Multikultural. Zawiyah: Jurnal Pemikiran Islam.

Desmita, D. (2009). MENGEMBANGKAN RESILIENSI REMAJA DALAM UPAYA MENGATASI STRES SEKOLAH. Ta'dib. https://doi.org/10.31958/jt.v12i1.150

Dinda Kartika, \& Oktafia, R. (2021). IMPLEMENTASI STRATEGI DALAM PENANGANAN PEMBIAYAAN MURABAHAH BERMASALAH PADA KSPPS AL-MUBAROK SIDOARJO. Jurnal Tabarru': Islamic Banking and Finance. https://doi.org/10.25299/jtb.2021.vol4(1).6598

Farikhatul 'Ubudiyah. (2020). Konseling Melalui Meditasi Lintas Agama di Vihara Karangdjati Yogyakarta. Al-Irsyad Jurnal Bimbingan Konseling Islam.

Firman. (2017). Peran Antropologi dalam Konseling Lintas Budaya di Era Masyarakat Ekonomi Asean (MEA). Prosiding Seminar Konseling 2017 (Profesi Konseling Menuju Masyarakat Ekonomi Asean).

Ganesan. (2016). Akhbar Tamil Nesan dan peranannya dalam perkembangan pendidikan Tamil di Tanah Melayu. Jurnal Penyelidikan Dedikasi.

Hermansyah, M. T., \& Hadjam, M. R. (2020). Resiliensi Pada Remaja Yang Mengalami Perceraian Orang Tua: Studi Literatur. Motiva Jurnal Psikologi. https://doi.org/10.31293/mv.v3i2.4950

Irman, I., Murisal, M., Syafwar, F., Silvianetri, S., Zubaidah, Z., \& Yeni, P. (2020). Membangun Kesadaran Spritual melalui Konseling Berbasis Surau dalam Pengembangan Pariwisata. Islamic Counseling: Jurnal Bimbingan Konseling Islam. https://doi.org/10.29240/jbk.v4i1.1421

Mahfuz, A. G. (2019). Hubungan Agama dan Budaya. Sosial Keagamaan Dan Pendidikan Islam.

Masna. (2013). Resiliensi Remaja Penyandang Tunanetra Pada SLB A Ruhui Rahayu di Samarinda. Psikoborneo.

Mirnawati et.al. (2016). Simbol Mitologi Dalam Karya Sastra Teks Al-Barzanji; Analisis Semiotika Roland Barthes Pada Pasal 4. Jurnal Diskursus Islam UIN Alauddin Makasar.

Nashihin, H. (2017). Pengertian Budaya. Konstruksi Budaya Sekolah Sebagai Wadah Internalisasi Nilai Karakter.

Rifaudin, M., \& . H. (2021). Studi Kasus Pengolahan Koleksi Jurnal Cetak di Perpustakaan Fakultas Psikologi Universitas Gadjah Mada Yogyakarta. JIPI (Jurnal Ilmu Perpustakaan Dan Informasi). https://doi.org/10.30829/jipi.v6i1.7512

Rofiqi, M. A. (2019). Relevansi Agama Dan Spiritual Dalam Konseling. JCOSE Jurnal Bimbingan Dan Konseling. https://doi.org/10.24905/jcose.v1i2.34

Sunarti, E., Islamia, I., Rochimah, N., \& Ulfa, M. (2017). Pengaruh Faktor Ekologi Terhadap Resiliensi Remaja. Jurnal Ilmu Keluarga Dan Konsumen. https://doi.org/10.24156/jikk.2017.10.2.107

Sunarti, E., Islamia, I., Rochimah, N., \& Ulfa, M. (2018). Resiliensi Remaja: Perbedaan Berdasarkan Wilayah, Kemiskinan, Jenis Kelamin, dan Jenis Sekolah. Jurnal Ilmu Keluarga Dan Konsumen. https://doi.org/10.24156/jikk.2018.11.2.157 
Supriatna, E. (2019). Islam dan Kebudayaan. Jurnal Soshum Insentif. https://doi.org/10.36787/jsi.v2i2.178

Thabroni, G. (2020). Pengertian Budaya, Unsur, Wujud \& Fungsi Menurut Para $k$. Serupa.Id.

Wati, W., \& Silvianetri, S. (2018). Pengaruh Konseling Islam Dalam Meningkatkan Kesadaran Sholat Berjamaah Siswa. Alfuad: Jurnal Sosial Keagamaan. https://doi.org/10.31958/jsk.v2i2.1443 